\title{
Towards community management to improve pedestrian mobility of the elderly
}

\section{Hacia una gestión comunitaria para mejorar la movilidad peatonal de las personas de la tercera edad} MARTÍNEZ-LIMA, Ayumi†*, GUEVARA-ROMERO, María Lourdes and FLORES-LUCERO, María
de Lourdes

Benemérita Universidad Autónoma de Puebla, Mexico.

ID $1^{\text {st }}$ Author: Ayumi, Martínez-Lima / ORC ID: 0000-0003-2058-9441, CVU CONACYT ID: 965551

ID $1^{\text {st }}$ Co-author: María Lourdes, Guevara-Romero / ORC ID: 0000-0001-7312-3499, Researcher ID Thomson: Q-55212017, CVU CONACYT ID: 336949

ID $2^{\text {nd }}$ Co-author: María de Lourdes, Flores-Lucero / ORC ID: 0000-0003-3849-0060, CVU CONACYT ID: 85792

DOI: $10.35429 / J S R .2021 .20 .7 .1 .12$

Received July 10, 2021; Accepted December 30, 2021

\begin{abstract}
The main theme of this article focuses on the study of the abandonment of neighborhoods or colonies that make up large cities in terms of the urban conditions that exist between its streets and avenues. In this case we refer to the América Norte neighborhood located in the east of the city belonging to the state of Puebla, Mexico. There are currently no adequate spaces for efficient pedestrian mobility, especially for the most vulnerable sectors such as the elderly, a sector that is the focus of this research. Therefore, the main objective is focused on carrying out a community management process that aims to offer strategies and actions to improve mobility conditions and pedestrian accessibility through citizen participation, all this with the collaboration of the board of directors, street representatives and institutions of the corresponding municipal government. The methodology used is developed from the complex systems from the actionresearch, in order to analyze and understand the problems from the social and urban environment that allows to broaden the perspective of the needs that reflects the social reality that exists in the neighborhood.
\end{abstract}

Pedestrian mobility, Accessibility, Urban infrastructure, Community manageme

\section{Resumen}

El tema principal de este artículo se centra en el estudio del abandono de barrios o colonias que conforman las grandes ciudades en función de las condiciones urbanas que existen entre sus calles y avenidas. En este caso nos referimos a la colonia América Norte situada al oriente de la ciudad perteneciente al estado de Puebla, México. En donde actualmente no existen espacios adecuados para una movilidad peatonal eficiente, especialmente para los sectores más vulnerables como lo son las personas de la tercera edad, sector al que corresponde el interés de esta investigación. Por consiguiente, el objetivo principal se centra en realizar un proceso de gestión comunitaria que tiene como fin ofrecer estrategias y acciones para mejorar las condiciones de movilidad y accesibilidad peatonal a través de la participación ciudadana, todo ello con la colaboración de la mesa directiva, representantes de calle e instituciones del Gobierno municipal correspondientes. La metodología utilizada se desarrolla a partir de los sistemas complejos desde la investigación-acción, con el fin de analizar y comprender la problemática desde el ámbito social y urbano que permita ampliar la perspectiva de las necesidades que refleja la realidad social que existe en la colonia.

Movilidad peatonal, Accesibilidad, Infraestructura urbana, Gestión comunitaria

Citation: MARTÍNEZ-LIMA, Ayumi, GUEVARA-ROMERO, María Lourdes and FLORES-LUCERO, María de Lourdes. Towards community management to improve pedestrian mobility of the elderly. Journal of Social Researches. 2021. 7-20:112.

\footnotetext{
* Correspondence to Author (Email: amtz_lima@hotmail.com)

$\dagger$ Researcher contributing as first author.
} 


\section{Introduction}

Pedestrian mobility is the action that people take to move from one place to another. It is the preferred non-motorized means of transport in the urban mobility pyramid, it promotes the existence of a constant movement in space among those who do it. And due to the flow that emerges from social interactions, the public life of urban environments is generated, which makes the constitution of public space possible. As it is the most basic form of displacement, users are commonly made up of different social actors, including the most vulnerable sectors, such as children, the elderly and the disabled. According to the National Human Rights Commission (2016) "mobility has become one of the priority issues to be addressed and resolved, so that conditions of well-being and prosperity are created for the population in urban areas."

In terms of pedestrian mobility for the elderly, various urban development plans, programs and strategies have been carried out that aim to reinforce the importance of generating action strategies to make the mobility of pedestrians more accessible and inclusive. to a vulnerable sector. However, on many occasions they are not always carried out with the same rigor as in the spaces where they are located in the nuclei of large cities, since in certain social sectors such as neighborhoods or neighborhoods, they do not reflect an urban development of their communities. streets and avenues, which as a consequence manifest problem for the mobility of people due to poor quality, poor signage and a deterioration of its infrastructure. This represents a major disadvantage for the elderly, who due to their conditions require moving in adequate spaces to facilitate their trajectories, without endangering their health and integrity.

In the case of the city of Puebla, based on data from the INEGI population census, (2020) it is among the 10 states with the largest population corresponding to the elderly sector and it is estimated that in the next years this sector is increasing.
A notorious example is the America Norte colony, founded approximately in 1937, located to the east of the city, which is one of the many colonies that have not been intervened since its foundation and as a consequence, a problem has developed of pedestrian mobility that interferes with the safety and integrity of the neighboring inhabitants, mainly the elderly, who, due to their difficulties to move around, due to their natural condition must adapt to the poor quality of public space, which represents a problem of social, political and economic interest that must be addressed directly to prevent it from becoming an unsustainable reality. As a result, it is important to highlight that as there is an increase in the elderly population, it is convenient to carry out a renovation in the urban infrastructure that manages to meet the needs that this sector requires in its pedestrian mobility.

Consequently, in the face of the urban problems that the North America neighborhood presents and that generate inadequate mobility due to not having been intervened in recent decades, the causes, difficulties and situations that the neighborhood presents are shown and with this the articulation of the stakeholders to identify the reasons why the necessary interventions have not been carried out. Therefore, a community management process is proposed as an alternative solution that integrates the inhabitants, neighborhood authorities, municipal government and academia, with based on the legal and normative instruments that are the guidelines to provide solutions adapted to the needs that arise in order to improve mobility and pedestrian accessibility for the elderly and the educational sector in the neighborhood.

This article is made up of three sections; The first refers to the theoretical framework, where the theoretical discussions and proposals that make up the subject of pedestrian mobility in relation to the community management process for the elderly sector are addressed. The second section shows the context of the study area, as well as the urban conditions that currently make up the America Norte neighborhood, which are the result of the diagnosis that was made through an instrument that was developed to obtain said information. 
In the third section, the characteristics of the neighborhood organization that exists in the America Norte neighborhood are shown, as well as the way in which the community management proposal is achieved that will help improve the conditions of mobility and pedestrian accessibility. Finally, the conclusions and bibliographic references are shown.

\section{Methodology}

The approach in which this analysis is developed is around complex systems, based on action research through successive approximations. Based on this, the following stages were carried out. In the first stage, a conceptual search focused on pedestrian mobility was carried out to identify the background of the study, as well as the theoretical integration of various authors who mention the importance of thinking about cities from an urban approach in the inhabitants and territorial spaces so that they can have decent mobility and accessibility.

In the second stage, those legal and normative instruments were investigated from an international, national, state, municipal and neighborhood scope, with urban and mobility approaches, as well as pedestrian accessibility, in order to obtain legal contributions for this investigation. Moving to the third stage, field trips were made and from this, a photographic survey was obtained to be able to know and evidence the current conditions of the North America colony. An evaluation instrument based on the technical standard for urban design and image of the municipality of Puebla was also carried out to diagnose the primary, secondary and tertiary roads of the same neighborhood.

Finally, population data were investigated based on the Population Censuses. 2010, 2020 and the INEGI Intercensal Survey to detect population estimates. After that, interviews and surveys were carried out with the inhabitants of the colony, as well as meetings with the board of directors, in order to know their opinion towards the urban conditions of the North America colony and based on the results obtained previously, A community management proposal was created, where social and institutional actors are involved to improve urban conditions of mobility and accessibility of the most vulnerable people, through strategies and actions.

\section{Theoretical approach}

\section{Pedestrians and their mobility in public spaces}

The relationships between the inhabitants of a city occur within a public space, which is defined as "the representation in which society becomes visible" (Borja and Muxí, 2000). Thus, the spaces, where the human being interacts, travels and carries out activities of different kinds, transforms the public space into a multifunctional space within the city, because it is not only occupied to move from one place to another, but also exist other concrete elements that promote the economic and social development of the localities, since a structure made up of shops, work and schools is generated that keep public life in constant change.

On the other hand, "the public spaces of a city are the essence of community life, and constitute a habitat that every citizen has the right to occupy and use" (Longás, 2017). In this way, public spaces are the representation that users express in their way of life and the way they appropriate them. For this reason, spaces must be created thinking about the needs of the inhabitants to generate effective mobility and accessibility, which in turn allows them to carry out activities without jeopardizing their road safety. In the same way, every inhabitant carries out his condition of pedestrian when he makes use of public spaces, based on the Pedestrian League within the illustrated charter of the rights of the pedestrian defines it as "the walker of the urban public space, classifying to them in the following way: people with disabilities, children, the elderly, women and men" (Pedestrian League, 2006). Consequently, the pedestrian is located in the highest part of the mobility pyramid, being the most desirable means of transport in the hierarchy of urban mobility.

That said, it is important to note that all the inhabitants of a city, at some point, become part of, or become members of, those groups of pedestrians, which is why all these groups require the same quality when traveling between public spaces, therefore, the importance of designing the roads and public spaces of cities arises in order to benefit everyone in the same way. 
Meanwhile, as mentioned above, in an urban environment of recurrent road traffic and constant social interactions, it represents, to a certain extent, a space of uncertainty for the elderly, who, due to their natural physical conditions, move at a slow pace. more cautious. In addition, they require adequate areas that allow them to move with dignity. And although numerous spontaneous accidents frequently occur on public roads, such as: collisions, runins or falls, this sector of the population, together with disabled people, becomes susceptible, as they are exposed to a latent risk; on the one hand, from those who make up the public thoroughfare every day, and on the other, from the physical units that make it up, such as streets, signage, infrastructure and urban furniture. Although from that perspective, vulnerability is presented to all users in their pedestrian condition.

However, older adults perceive to a greater extent the impact that emerges from the poor conditions of the urban environment and that indefinitely reduces the safety of their movement, combining the daily repercussions that become problems of pedestrian mobility. Even more so when they belong to conurbation areas of large cities or areas of precarious road conditions. This means that the design and urban infrastructure plans have a certain temporality, which to a certain extent excludes the needs and conditions of the vulnerable sectors that cross all social classes. In this way, the application strategies and urban development plans are technically only intended to reconfigure the urban infrastructure, mostly for a population that is capable of adapting to the dizzying public life of cities, which explains the social segregation for adults. greater. Therefore, it is suggested to find tools, methods, strategies and / or mechanisms of action to help generate alternatives to improve the safety and integrity of elderly pedestrians. Above all, promote a sense of social inclusion in the urban infrastructure from the locality, through citizen participation, neighborhood organizations and relevant authorities.

\section{Accessibility in the public space environment}

Another element that is also currently affected in public space is accessibility, which aims to improve the conditions of the urban environment so that all members of society can make full use of it (Universal Accessibility Manual, 2010).
It is a concept that coincides with the interests applied within pedestrian mobility and that together seek to find improvement alternatives for the benefit of pedestrians. Since, in recent years, cities with their accelerated and disorderly expansion are increasingly moving away from the objectives of these proposals, since the needs of the people do not fully correspond, due to the change in urban morphology, which as a consequence, causes the problem to be diluted in an irregular transformation in the infrastructure of the streets and avenues, where, as mentioned, the most vulnerable population sectors are the most affected when facing a real problem of urban accessibility that interrupts their integrity.

In the same way, accessibility has acquired a relevant importance within society, a proof of this is that, in the same evolution of cities, it is an essential element for those development plans, as well as for public works or infrastructure urban. However, in the reality of Mexico, the situation is not as it would be desired, since the most benefited in those interventions within the cities, is the motorized transport system, which, in the matter of accessibility, the pedestrian sector ends for being in the background.

On the other hand, according to Peralta (2006), accessibility is the right to use the city and its services without any restriction for all its inhabitants, regardless of their height, weight, age, gender, culture, or disability. According to Reyes (2007), it is the possibility of entering, staying and mobilizing independently throughout the city and enjoying its spaces and elements in adequate conditions of security and autonomy. In other words, accessibility must provide in a city that equity in pedestrian mobility for all sectors of the population and conditions of equality, comfort and safety are provided.

Regarding the above and in a more general way, we find universal accessibility where the concept of Universal Design or Design for All arises:

It "seeks to stimulate the development of attractive and commercial products that are usable by any type of person and is aimed at the design of solutions linked to construction and objects that respond to the needs of a wide range of users" (Mace, 2010, p. 8). 
This concept comes from an urban approach that aims to think about the environment, roads and public spaces of a city in an urban sense, so that, in the movement of people in relation to their space, an accessible pedestrian mobility is generated and universal, where there are no physical barriers that prevent everyone from living an autonomous life. Therefore, within the public space, criteria that offer physical-spatial conditions must be retaken, which provide the user with elements of accessibility, road safety, pedestrian safety, connectivity, legibility, comfort and aesthetics, which makes the analysis of all these essential. concepts that are related to each other.

\section{Colonia América Norte, poor pedestrian mobility in urban conditions}

The city of Puebla is the capital of the state of Puebla, which is located in the center-east of the Mexican territory. It has a population of 6 million 583 thousand 278 inhabitants according to the results of the population and housing census, INEGI (2020). In addition to this, the América Norte neighborhood is located in the context that connects the north and northeast areas of the city, as shown in figure 1 . Historically, this place was considered as the periphery of the eastern side of the city of Puebla and was founded in approximately 1937 , administered at that time by Governor Dr. Gonzalo Bautista Castillo, who at the time was the one who acquired land in that place to found what is now known as the North America colony.

The neighborhood has a total area of $95,313.62 \mathrm{~m}^{2}$ and a perimeter of 1,752.23 meters, having a reticular layout made up of 19 blocks and 396 homes. Within the neighborhood, private ones predominate with an average width of 7.5 meters in their sidewalks and two roads that cross the neighborhood: Avenidas México and Washington that measure around 9.5 meters with sidewalks of 2.25 meters.

Therefore, since it is a neighborhood established decades ago, it is common that some parts of the infrastructure of its streets and avenues are still preserved without some type of innovation or urban maintenance, which makes the deterioration conditions that can generate more noticeable. problems for the mobility of the inhabitants and as a pedestrian.
According to the spatial analysis of the colony, there is a large number of elderly inhabitants who travel daily, who expose their safety in their daily journeys.

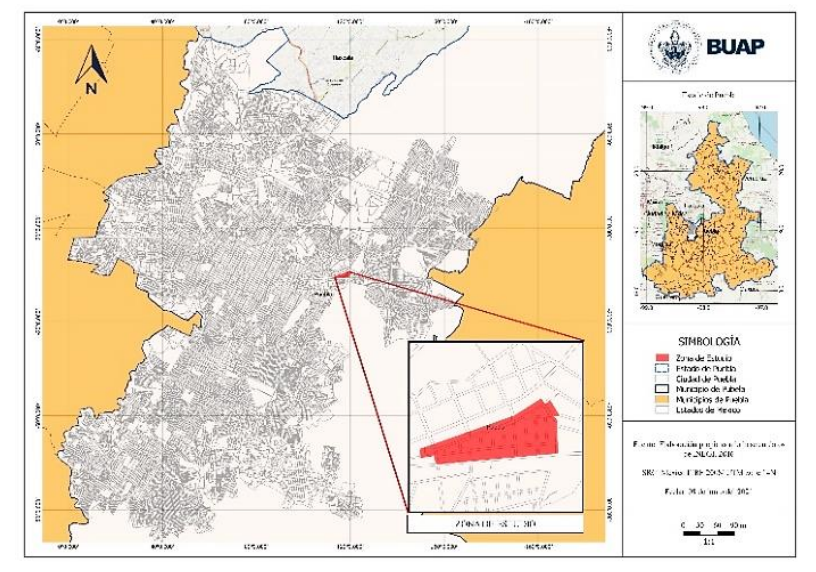

Figure 1 Location of the America Norte neighborhood in the city of Puebla

Source: Own elaboration based on SCINCE by INEGI, 2016

The colony has 1,017 inhabitants, of which $17 \%$ correspond to the population from 0 to 14 years old, $22 \%$ to the population from 15 to 29 years old, $38 \%$ to the population from 30 to 59 years old, $19 \%$ correspond to to the population aged 60 years and over and $3 \%$ to the population that has a disability, as can be seen in figure 1 , the population aged 30 to 59 is the highest percentage, which in a few years will be the population of the The elderly and by not improving mobility conditions within the colony, they will be vulnerable to this situation.

\section{Population percentage}

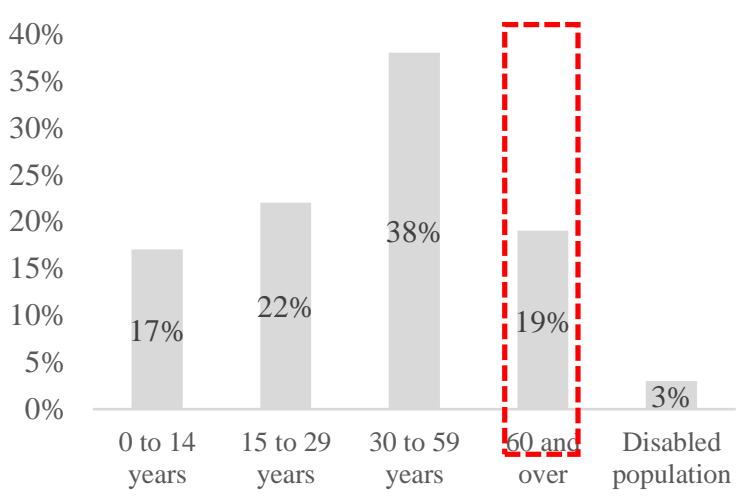

Graphic 1 Population graph of the inhabitants of the North America colony

Source: Own elaboration based on the INEGI Intercensal Survey, 2015 
The neighborhood has main roads and high traffic flow that are; Av. 14 Oriente, 36, 38, 40 Norte, 12 Oriente and Xonaca Boulevard, as well as the secondary and primary roads most traveled by settlers, such as Calle 16 and 18 Norte. The roads and equipment of the neighborhood are not the most favorable for its inhabitants, since they do not have the conditions that the Technical Standard for Urban Design and Image for the Municipality of Puebla determines. Next, Figure 2 shows a series of photos that show the aforementioned within the colony.

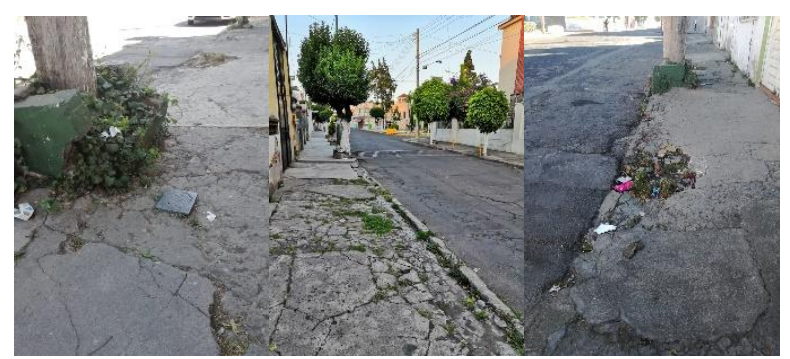

Figure 2 Urban conditions of the North America colony Source: Martínez A., 2019

As mentioned above, the pedestrian becomes a fundamental actor when we talk about mobility, which leads us in this study to delve into the sector of the elderly in the North America neighborhood, as they are the most vulnerable to the problem that presents the study area. In this way, one of the inhabitants of the colony, offered to this investigation her point of view as an older adult regarding the experience of walking in the context of the study area, where she related the following:

Testimony 1 "For me and with my years on top, even though I can still take care of myself, it is difficult for me to travel through the neighborhood to do my errands or go for a walk, because the streets are fractured, incomplete and in a state that They do not allow me to walk safely and the truth is that I am afraid of having an accident. " (Ana Claudia, May 26, 2019).

Indeed, this testimony allowed knowing and understanding the problem from the perspective of an inhabitant of the North America neighborhood, observing that the problem of having the poor conditions of the sidewalks, urban obstacles in the streets, unevenness, really make it difficult to move on the streets. people specifically, that of the elderly.
As a result of this, the need arises to analyze in greater depth the mobility and accessibility problems that the North America colony presents.

\section{Urban conditions of a forgotten neighborhood}

In this section, an instrument was designed in order to assess the urban conditions within the America Norte neighborhood as shown in Table 1. Carried out based on the technical standard for urban design and image of the municipality of Puebla (2017), which mentions that: "the pedestrian infrastructure must be tailored to all people as walkers in the urban space, regardless of their age, gender, physical or intellectual condition." In other words, that infrastructure must be designed and created for all the inhabitants who share a common space, where their physical characteristics are not an impediment.

In the first instance, the identification of the urban elements of the streets was carried out to create a classification that would allow obtaining a broader panorama of what are the conditions that the inhabitants face on their journeys, especially the elderly, who are the most vulnerable sector within the colony. As part of the instrument, the elements that were retaken were divided as follows, where to qualify as good they had to correspond to the following characteristics:

Street: for the analysis of this element, it was observed if the sidewalk was in good condition, also if these streets are continuous, with the existence of ramps for garages and disabled people, as well as speed bumps.

Road intersection: pedestrian crossings, ramps for the disabled, traffic lights and transport stops were examined to identify the number of existing units within the neighborhood, as well as their conditions. 


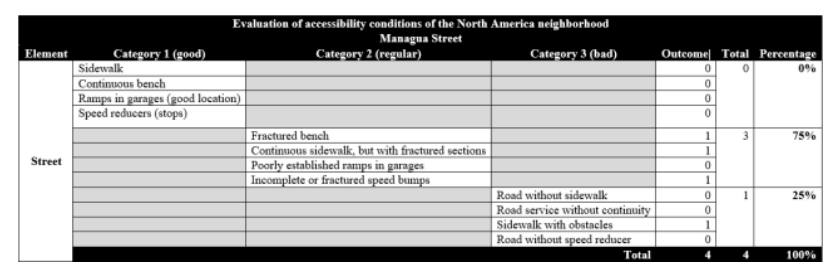

Table 1 Example of the result of the evaluation instrument Source: Own elaboration based on the technical standard for urban design and image of the municipality of Puebla, 2017

Urban furniture: the urban equipment that is installed within the neighborhood was analyzed to determine the quality and existence of garbage cans, benches, telephone booth and public lighting.

Signs: preventive and restrictive signs, school zone, nomenclature and the sense of movement existing in the neighborhood were observed.

The aforementioned urban elements were retaken because together they make them respond and adapt to urban spaces, in this case if these elements are in a deterioration they will damage the mobility and accessibility of the inhabitants, but especially that of the people of the elderly, therefore, their classification would no longer be good if not, fair or bad, as can be seen in table 2, an example of what corresponds to the general result of the diagnosis made on one of the streets of the colony.

\begin{tabular}{|l|r|r|r|l|}
\hline \multicolumn{1}{|c|}{ Element } & Good & Regular & Bad & \multicolumn{1}{|c|}{$\begin{array}{c}\text { Final } \\
\text { score }\end{array}$} \\
\hline Street & $0 \%$ & $80 \%$ & $20 \%$ & Regular \\
\hline $\begin{array}{l}\text { Road } \\
\text { Intersection }\end{array}$ & $0 \%$ & $25 \%$ & $75 \%$ & Bad \\
\hline $\begin{array}{l}\text { Urban } \\
\text { furniture }\end{array}$ & $25 \%$ & $25 \%$ & $50 \%$ & Bad \\
\hline Signage & $0 \%$ & $60 \%$ & $40 \%$ & Regular \\
\hline
\end{tabular}

Table 2 Result of the diagnosis applied in the North America colony

Source: Own elaboration based on the results obtained from the diagnosis, 2020

The situation and perception of the inhabitants regarding the conditions of pedestrian mobility

The perception and opinion of the inhabitants is important because they are the ones who live the reality and problems of pedestrian mobility in said neighborhood.
Likewise, Carmona (1996) argues that participation and democracy have a close relationship, since participating means exercising rights and fulfilling duties as citizens. In other words, participation is intended for citizens to influence and act jointly with the relevant public institutions to provide solutions to common problems. Starting from the generation of a citizen consultation, to locate the main needs that arise from the community, which opens the approach to proposals or strategies that they can jointly carry out in order to achieve that the community execute a unified work and in common agreement to assert their social participation in these activities that will improve their environment and context, in addition to reinforcing communication between neighbors and the board of directors.

Therefore, a series of interviews were applied to 33 people who live on Panama Street in the neighborhood. These interviews were applied in an analogous and digital way, where it was observed that the social perception of the neighborhood is directed to common problems, linked to the mobility and accessibility of pedestrian areas within the neighborhood. As can be seen in graph 2, where the inhabitants mentioned that they have the difficulty of making their journeys through the streets of the neighborhood, due to the fact that the sidewalks are in poor condition $(42.30 \%)$ or they encounter urban obstacles in their road $(21.30 \%)$, as well as the lack of signage $(21.20 \%)$ and non-existent pedestrian crossings $(15.20 \%)$, which generate problems in their daily movements, violating their integrity and safety.

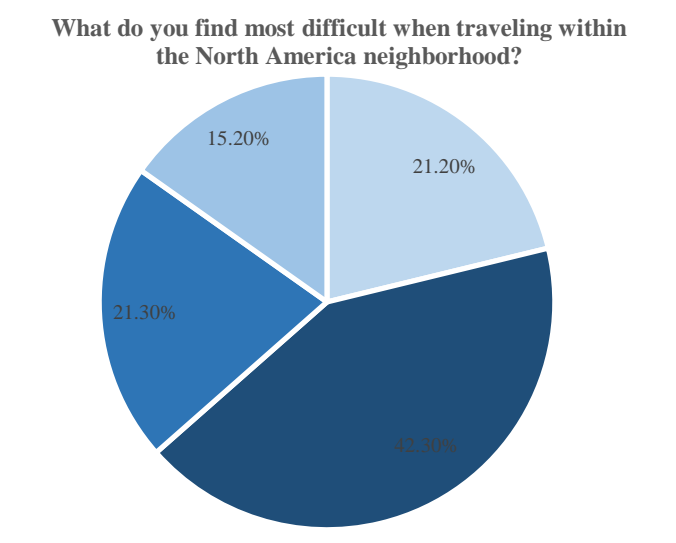

Graphic 2 Digital questionnaire results

Source: Own elaboration based on the results obtained from the applied questionnaire, 2021 
That said, within the perception of the inhabitants, it was possible to identify that, for them, the conditions of the streets limit and make it difficult for them to travel, which is why the majority described them as fair due to the deterioration in urban infrastructure. On the other hand, the older people who were interviewed mentioned that it is even more difficult for them to move safely because they face great mobility and pedestrian accessibility problems, which make their movements within the neighborhood more unsafe. Likewise, there is a considerable percentage that is willing to participate to improve this problem that does not allow and limit daily or daily transfers within the neighborhood and the immediate context, as can be seen in graph 3, where the highest percentage mentions that if you are willing to work towards a change that improves your mobility and pedestrian accessibility.

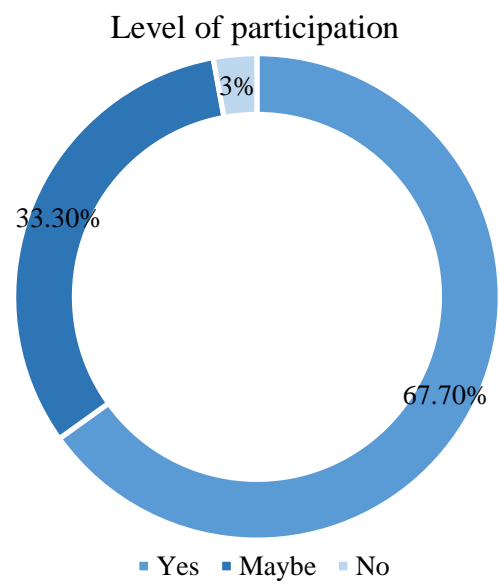

Graphic 3 Digital questionnaire results

Source: Own elaboration based on the results obtained from the applied questionnaire, 2021

Otherwise, the inhabitants of the North America colony have common objectives that were identified through the diagnosis and based on the mobility conditions within the colony, it was possible to identify that the neighbors are aware of the bad conditions found in the neighborhoods. streets of the colony. However, although the majority acknowledged not participating in any improvement strategy, they showed willingness to collaborate in neighborhood participation projects in their neighborhood.

\section{A legal framework in terms of pedestrian mobility that forgets the neighborhood scale}

In this area, an analysis was made of the legal and normative instruments found in the territorial scales; international, national, state and municipal, as shown in Figure 3, with the aim of providing a frame of reference that is inserted in pedestrian mobility issues, which served as legal support for this research. These instruments are important to be able to generate changes in the different territorial scales, from large cities to small neighborhoods, because they are the legal support to work and improve the problems that affect, in this sense, the pedestrian mobility of people.

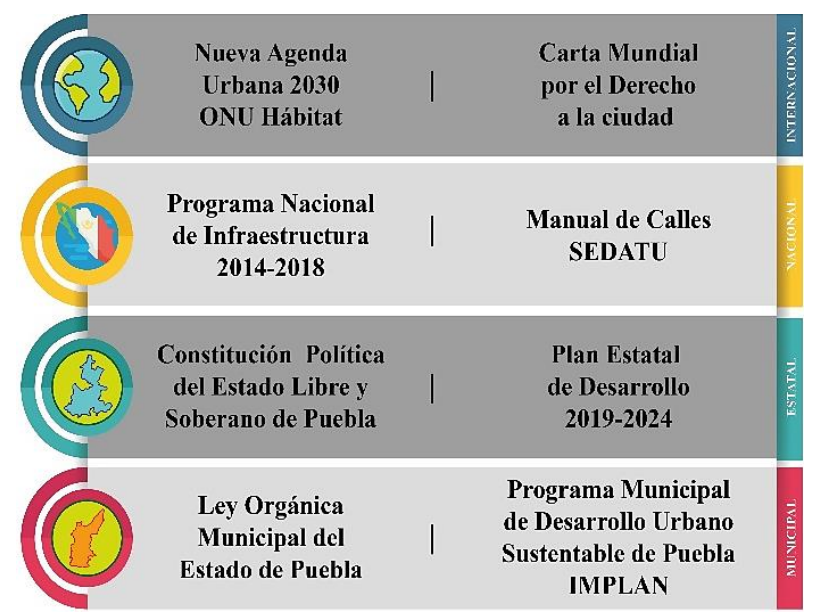

Figure 3 Table of legal and regulatory instruments on mobility and pedestrian accessibility issues

Source: Own elaboration, 2020

This analysis allowed us to know the scope of these instruments, likewise, to know to what level of the territorial scales they are inserted to improve the conditions of mobility and pedestrian accessibility, where it was possible to verify that said legal and regulatory instruments when they go down to a neighborhood scale They are not applied, because they are being repealed and these are not designed for a neighborhood scale, revealing urban deterioration that little by little is making more difficult the mobility and pedestrian accessibility of the inhabitants of certain neighborhoods, as is currently the case in the North America neighborhood. 


\section{Community management to improve pedestrian mobility conditions}

Community management can be defined as an interdependent set of individual or collective, natural and institutional actors that seek a solution where they can contribute to the elaboration of the solutions that will be given to these problems (Friedberg, Erhard, 1993). That is to say, part of the collaborative work between the inhabitants, since it is essential to have citizen participation to be able to carry out actions and strategies that allow the and generation of alternatives for the improvement of their environment, as happens in the North America colony.

The Institute of Policies for Transportation and Development mentions that participation as a community process is defined as the process in which citizens organize, establish their objectives and work together through non-governmental community organizations to influence the decision-making process. decision-making (as mentioned in Gilbreath and Zakharchenko, 2002). This community participation can be fundamental in those neighborhoods to give way to those actions that allow the improvement of public spaces or simply solve the problems that are faced in their environment, and as Dascal and Segovia (2000) mentioned, said participation Citizenship can be carried out from non-governmental organizations, an example could be, those directive boards or citizen councils, which are currently operational bodies recognized by COREMUN.

Likewise, and based on the aforementioned, some elements were taken up to show a community management proposal, as shown in Figure 4.

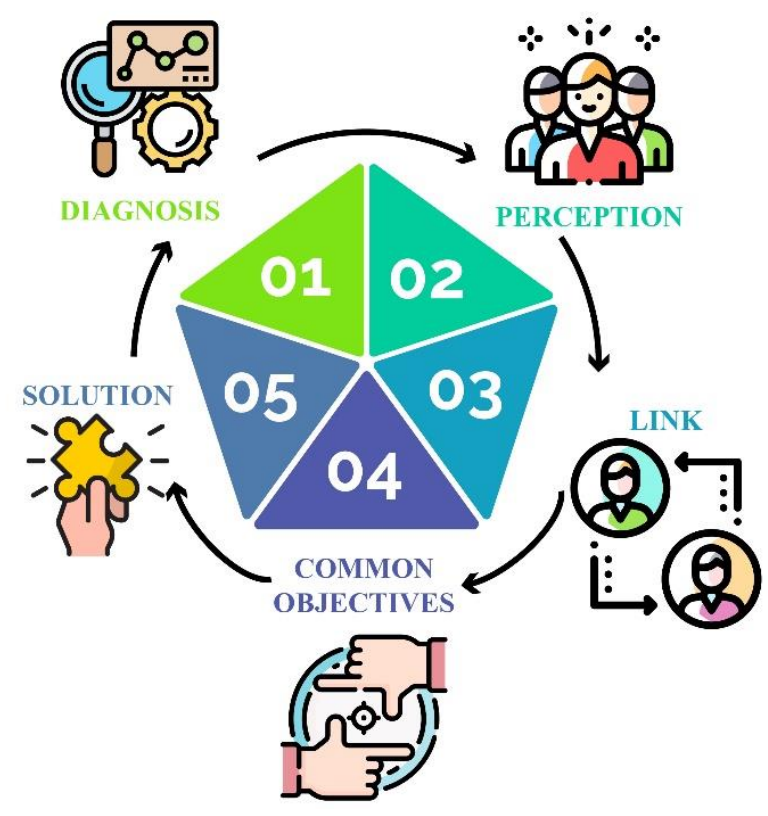

Figure 4 Diagram of elements to follow for a community management proposal

Source: Own elaboration, 2021

In accordance with the previous representation, it is intended to generate a proposal for community management to solve various problems in an urban setting. In this case and under this research, these elements are developed in order to make alternative solutions to the problem of mobility and accessibility that the inhabitants of the North America colony face.

For this research, the diagnosis was made that helped to obtain the results of the mobility and accessibility conditions that the neighborhood currently presents for its inhabitants. After that, the inhabitants' perception of the problem presented by the colony was analyzed as mentioned throughout this article. Within the element of linkage, and with the previous results, it was possible to identify that the neighborhood, as it presents great weaknesses in urban areas, its linkage presents various deficiencies, since as it could be observed, that although it has a well-formed board of directors and that has tried to have communication with its inhabitants, becomes fragmented at the time of dealing with a specific problem, since it goes beyond what they can solve, since it requires a management and request to more consolidated authorities, and As a consequence, an indefinite abandonment arises in the colony, which today has prevailed in the same way in recent years, since its sidewalks, streets and avenues are seen with great deterioration, thus producing a great mobility and accessibility problem. 
Therefore, it is important to identify the common objectives, which will be the basis to give way to the actions and strategies that will be a possible solution, in this case, to the problems of accessibility and pedestrian mobility for the inhabitants of the neighborhood. Therefore, a scheme is proposed, which can be seen in Figure 5, which shows how the community management process could be in neighborhoods, such as the America Norte neighborhood, so that there is communication that helps to strengthen the relationships between the identified actors and the common good can be obtained for all that are part of a given urban space. In this scheme, two levels of communication are shown; The first proposes to strengthen the relationship between the inhabitants, the street representatives and the board of directors to be able to work and generate strategies and actions that give way to urban improvement as a possible solution to the problems identified in the study area, such as the implementation of workshops and meetings between neighbors to unify the neighborhood and thus contribute collectively.

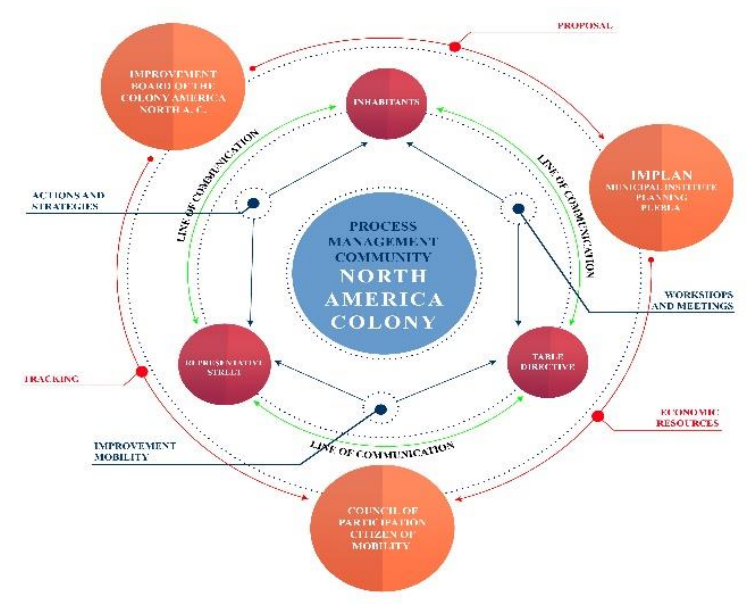

Figure 5 Diagram of a management process Source: Own elaboration, 2021

The next level that is shown in the scheme of the community management proposal is the communication that must exist between those actors that make up the neighborhood organization, towards those institutions and councils of citizen participation. In this sense, the one that corresponds to the area of mobility of the city of Puebla, where through this communication, the board of directors that is called the North America Neighborhood Improvement Board, can deliver a proposal for urban improvement to the citizen council and together with the education sector to provide adequate follow-up to obtain favorable results for the inhabitants of the colony.
This proposed outline of a community management model, which involves neighborhood organization and the necessary communication, can be of great help to solve mobility problems and pedestrian accessibility, both for this neighborhood and for others that are identified with deficiencies. in its urban structure for the most vulnerable people, in this case, for the elderly, which they can carry out through strategies and actions, from cleaning brigades among the inhabitants to achieving a job through urban planning tactical, which allows settlers to carry out first-hand actions that benefit their mobility and pedestrian accessibility within those neighborhoods or neighborhoods and get the inhabitants of said area to participate and empower themselves in their public space and in this way they can change and improve those conditions that hinder your daily transfer.

\section{Acknowledgments}

I am grateful to CONACYT for the scholarship granted to carry out the studies in the master's degree in Territorial Planning (Ayumi Martínez Lima). And the collaboration of street representatives and the Board of Directors of the North America neighborhood.

\section{Conclusions}

In the first instance, the importance of resuming the issue of public space within large cities should be highlighted, of which, historically determined, define and manifest the most representative features of communities endowed with a great identity load and architectural legacy, which reflect through its structure, all the elements that are involved in the social construction of space. Public space as a site of constant social, economic and political interactions must be designed for all social sectors that make use of it, in such a way that, regardless of physical or socioeconomic condition, in its constant use, security, inclusion and integrity are fundamentally essential aspects to ensure the social equity of citizens in their condition as pedestrians. 
With respect to the neighborhoods and neighborhoods that are in the surroundings of the nuclei of the cities, they present to a greater extent urban infrastructure problem that affect their mobility and favor a precarious accessibility for the most vulnerable pedestrians, as is the case. of the North America colony, in which urban conditions show a significant deterioration that has increased over time, leaving great consequences for the inhabitants.

Therefore, to dignify public space and improve urban conditions, it is important to have a base of various legal instruments that help improve said conditions in neighborhoods such as North America. Derived from the above, the legal and regulatory instruments that seek to generate improvement strategies in terms of mobility and universal accessibility were analyzed, which seek to develop improvement alternatives for mobility and accessibility at all social scales, ranging from international to international. neighborhood. In the population sector made up of neighborhoods or neighborhoods, these policies and development plans turn out to be ineffective depending on their application, because they do not correspond to the true needs of vulnerable groups, who turn out to be the most affected.

\section{Acronyms}

COREMUN - Regulatory Code for the Municipality of Puebla

INEGI - National Institute of Statistics and Geography

ITDP - Institute for Transportation and Development Policies

\section{References}

Boudeguer Simonetti A., Prett Weber P. y Squella Fernández P. (2010). Manual de Accesibilidad Universal. Santiago de chile.

Borja J., Muxí Z. (2000) El espacio público, ciudad y ciudadanía. Barcelona. https://www.researchgate.net/profile/Zaida_Ma rtinez3/publication/31731154_El_espacio_publi co_ciudad_y_ciudadania_J_Borja_Z_Muxi_pro 1_de_O_Bohigas/links/543fbcd00cf2be1758cf9 779/El-espacio-publico-ciudad-y-ciudadania-JBorja-Z-Muxi-prol-de-O-Bohigas.pdf
Comisión Nacional de los Derechos Humanos (2016). Movilidad, vivienda y derechos humanos, México. http://appweb.cndh.org.mx/biblioteca/archivos/ pdfs/cartilla-Movilidad-Vivienda-DH.pdf

Friedberg, Erhard, 1993. "Las cuatro dimensiones de la acción organizada" en Gestión y política púdica, CIDE, México, vol. II, núm. 2.

Gilbreath, Gina y Olha Zakharchenko (eds.). (2002). Citizen participation handbook. Kyiv, Ucrania: International Centre of Policy Studies. Recovered from: http://siteresources.worldbank.org/INTBELAR US/Resources/eng.pdf

Google maps (2020). Mapa de la colonia América Norte. Puebla, México.

Google Eatrh Pro (2020). Mapa de la colonia América Norte. Puebla, México.

H. Ayuntamiento de Puebla (2017). Programa de movilidad urbana sustentable para el municipio de Puebla. México- Puebla.

ITDP (2014), Manual de participación en políticas de movilidad y desarrollo urbano. México

INEGI. Encuesta intercensal, 2015

INEGI, Censo de Población y Vivienda, 2020

INEGI, SCINCE, 2020

Instituto Nacional de Estadística y Geografía (2016). Estadísticas a propósito del Día Internacional de las Personas de Edad (1 de octubre). México. INEGI. Pág. 1.

Longás M. y Contrucci Lira P., (2017) La dimensión humana en el espacio público, recomendaciones para el análisis y el diseño. Santiago de Chile.

Liga Peatonal (2016). Carta ilustrada de los Derechos del Peatón. http://ligapeatonal.org/wpcontent/uploads/2016/08/CartaDerechosPeaton _Web.pdf

Mayer M. S., (2005), Colonias de puebla "La colonia América", BUAP, México. 
Naciones Unidas (2015). Declaración Universal de los Derechos Humanos (DUDH). https://www.un.org/es/documents/udhr/UDHR_ booklet_SP_web.pdf

Naciones Unidas (2018), La Agenda 2030 y los Objetivos de Desarrollo Sostenible: una oportunidad para América Latina y el Caribe. Recovered from: https://www.gob.mx/agenda2030

Orden Jurídico Poblano, (2015) Norma Técnica de Diseño e Imagen Urbana para el Municipio de Puebla, secretaria general de gobierno.

Peralta, J. (2006). Discapacidad y accesibilidad. La dimensión desconocida. Perú. Fondo Editorial del Congreso del Perú.

QGIS (3.12.3) [Software] (2020).

Reyes, A. C. (2007). Ciudad para todos. UNAM.

Ron Mace (1941 - 1998) Creador del término "Diseño Universal"

Segovia O. y Dascal G. (2000). Espacio público, participación y ciudadanía. Ediciones SUR. Santiago de Chile

Valenzuela-Montes, L.M., Talavera-García, R. Entornos de movilidad peatonal: una revisión de enfoques, factores y condicionantes. Universidad de Granada, Granada, España. Revista latinoamericana de estudios urbanoregionales, Vol. 41, núm. 123-.2015. 